American Research Journal of Agriculture

ISSN (Online) : 2378-9018

Volume 5, Issue 1, 1- 15 Pages

DOI: 10.21694/2378-9018.19001

AMERICAN RESEARCH JOURNALS

An Academic Publishing Hause

\title{
Review on Hide and Skin Value Chain in Ethiopia
}

\section{Tilahun Kenea}

Department of Agribusiness and Value Chain Management, Mettu University, Mettu, Ethiopia. tilahunkenea09@gmail.com

\begin{abstract}
Ethiopia's economy is predominantly agricultural where the livestock sub-sector plays substantial role. Hides and skin is an important strategic sector for the economic and industrial development of Ethiopia. Though the country has very good potential for supplying finished skins and hides products to the world market, the quality of skins and hides supplied has rather deteriorated over time. Therefore, this seminar was conducted to review hide and skin value chain in Ethiopia, to review hide and skin value chain actors, maps and its value addition in Ethiopia, to review the major constraints and opportunities of hide and skin in Ethiopia, to review hides and skins production, utilization and its constraint in Ethiopia and to review hide and skin marketing and its constraints in Ethiopia. Poor quality of hides and skins, Poor animal husbandry, Improper preserved hides and skins, Lack of price incentives, absence of quality grading, reflections of the economic policy, market information, and requirements from the tanneries and end market are main challenge observed hide and skin value chain. Creation of awareness among extension staff, butchers, collectors, tanners and other stakeholders and the general public of the economic importance of hides and skins are very important. Developing Clear pricing system based on grading and standard of hide and skin and improving access to market information As well as Clear policy and strategy for the development of hide and skin sector should be developed by Member State that have not done so far.
\end{abstract}

Keywords: Hide and skin, value chain, Actors, marketing constraints

\section{INTRODUCTION}

In Ethiopia Agricultural development is considered a priority by the Government for stimulating overall economic growth, reducing poverty and achieving food security. The agricultural sector of Ethiopia accounts for about $42 \%$ of GDP, more than $80 \%$ of export, and $85 \%$ of employment (MOFED, 2011). The sector plays a major role in the national economy and it is the source of income and employment for the rural population (Joseph Hain, et.al. 2015).

The livestock sector contributes $19 \%$ of GDP and 16-19\% of the foreign exchange earnings of the country. The recent livestock population of Ethiopia estimates that the country has about 57.83 million heads of cattle, 28.04 million sheep, 28.61 million goats and 60.51 million poultry (CSA, 2016). With the rapidly growing population, increasing urbanization, and rising incomes, domestic demand for meat, milk and eggs is expected to increase significantly for the foreseeable future. Furthermore, the country's foreign exchange from livestock product is increase, especially for red meat to gulf and within Africa, as well as leather and other livestock product to Europe (MOA, 2012).

Cattle, sheep and goats are important source of income for agricultural community and are also one of Ethiopia's major sources of foreign currency through exportation of live animals, meat, hide and skin (Dessieet al., 2010).

Hide from cattle and Skins from goats and sheep are important economic products contributing for the largest share to the total and agricultural export commodities (Foodand Agriculture Organization (FAO, 2005) followed by live animals (Ayele et al., 2003).

www.arjonline.org

Page 1 
In 2011 Ethiopia earned 139.28 million USD from export of finished leather, shoes, garments and gloves to foreign country's (CSA, 2011). Based on annual off take rates of 7.12\% for cattle, 31.11\% for sheep and 35.37\% for goats, the potential production is estimated at 3.7 million cattle hides, 8.7 million sheepskins and 8.1 million goat skins in 2011/2012 (FAO,2011).

Hides and skins contribute much to the export earnings from the livestock sector. In addition, it has a large contribution to the leather industry in the country. Ethiopia has been exporting hides and skins in the past 100 years (Girma, 2003). Trade in hides, skins, leather and leather manufactures have been in a great growth at an average of about 12\%over the last 30 years, reaching to around US\$ 53.8 billion in early 2000.

Commodity trade patterns have changed during a period between 1999 and 2008 and practical methods for evaluation and classification of skin are necessary (FAO, 2010).

The current utilization of hides and skins in Ethiopia is estimated to be $48 \%$ for cattle, $75 \%$ for goat and $97 \%$ for sheep with expected off take rate of 33, 35 and 7\% for sheep, goats and cattle, respectively (Mahmud, 2000). Hide and skin production is significantly increased in number in Ethiopia, but the efficiency of the market is not assessed (FAO, 1999).

The value chain concept has been applied in both the crop and livestock sectors as an approach for assessing potential interventions from a development perspective (Rich et al. 2010). This is particularly important because the livestock development context for different livestock commodities in different regions is variable and dynamic.

\section{Objective of the Seminar}

\section{General Objectives}

To review hide and skin value chain in Ethiopia

\section{Specific Objectives}

$>$ To review the Production and Utilization of Hides and Skins in Ethiopia

$>$ To review hide and skin value chain actors, maps and its value addition in Ethiopia

$>$ To review the major constraints and opportunities of hide and skin value chain in Ethiopia

$>$ To review hide and skin Marketing, and its Constraints in Ethiopia.

\section{Methodology}

This senior seminar is reviewed by referring different studies, published documents, guide books, international journals and proceedings.

\section{LITERATURE REVIEW}

\section{Concepts and Definition of Value Chain}

The term 'Value Chain' was used by Michael Porter in his book “Competitive Advantage: Creating and Sustaining superior Performance" (1985).

The complex network of activities carried out by different actors in multiple enterprises along a value chain means that attention must be paid to the activities that people are involved in, how they are linked together through services such as transportation, insurance, telecommunications, quality control, and management coordination (Arndt and Kierzkowski, 2001). Whereas the flow of goods is crucial in value chains, other determinants of value chain participation such as credit/financial flows, changes in ownership rights and markets need to be considered (Coles and Mitchell 2011). 
Value chains can either be market driven or relation-based depending on the form of governance they adopt (Farnworth 2011).

Riisgaard et al. (2010) noted that adopting the value chain approach as a development strategy provides an opportunity for all actors to understand each other's functions and the activities involved; increase their viability, visibility, voice and market share; and identify and correct barriers and gaps that cause inefficiencies.

Value chains can either be market driven or relation-based depending on the form of governance they adopt (Farnworth , 2011).

Porter linked up the value chains between firms to form what he called a value system. In value chain analysis, the focus is mainly on the benefits that accrue to customers such as variety of products, the interdependent processes that generate value and the resulting demand and funds flows that are created (Feller et al. 2006).

$A$ value chain comprises of interlinked value-adding activities that convert inputs into outputs which, in turn, add to the bottom line and help create competitive advantage.

Supply chain is the portion of the value chain that focuses primarily on the physical movement of goods and materials, and supporting flows of information and financial transactions through the supply, production, and distribution processes.

Value addition is simply the act of adding value to a product, whether you have grown the initial product or not. For farmers, value addition has a particular importance in that it offers a strategy for transforming an unprofitable enterprise into a profitable one (MSU, 2005).

Value chain actors are those involved in supplying inputs, producing, processing, marketing, and consuming agricultural products (Getnet, 2009).

Value chain analysis Rubin et al. $(2008,13)$ described value chain analysis (VCA) as the process of documenting and analysing the operation of a value chain, and usually involves mapping the chain actors and calculating the value added along its different links'.

Value chain analysis does not stop at the level of the actors or groups of firms, producers or market actors. It also draws attention to the national system of innovation-the network of institutions which support economic actors (Kaplisky and Morris 2000).

It identifies vertical and horizontal components in a system of stages/nodes of physical transformation processes that are inter-linked by transactions that occur either in the same firm or between firms in similar or different geographic locations (Mayoux and Mackie 2007).

Value chain map is a visual presentation of the way that the product flows through the different stages of the chain from production to the consumers.

\section{Development of the Hides and Skins Sector in Ethiopia}

The hides, skin and leather is a critical strategic sector for the economic and industrial development of Ethiopia. It has an abundant and renewable resource base in Ethiopia's large population of cattle, sheep and goats. It is labor-intensive with the potential to be a major source of employment all along its value chain.

There are 21 tanneries in the country, having an average tanning capacity of approximately 4000 pieces of hide and 30,000 pieces of skin/ day (Ethiopian Investment Agency 2008).

In Ethiopia hides and skins contribute much to the export earnings from the livestock sector. In addition, it has a large contribution to the leather industry in the country. Girma (2003) described that, Ethiopia has been exporting hides and skins in the past 100 years. The country has big potential to develop the sub-sector. 
In 2002 hides and skins represent major source of foreign exchange earnings for the country accounting for $14-16 \%$ of the total export revenue. At present, leather is used in various applications.

Hides and skins, raw materials for the tanning industry, are renewable and easily perishable resources (Arugna, 1995). Though the country has very good potential for supplying finished skins and hides, and leather products to the world market, the quality of skins and hides supplied has rather deteriorated over time (Kebede and Fetene 2012).

Globally, livestock contributes about 40 percent to the agricultural gross domestic product (GDP) and constitutes about 30 percent of the agricultural GDP in the developing world (World Bank, 2009).

In Ethiopia Agricultural development is considered a priority by the Government for stimulating overall economic growth, reducing poverty and achieving food security. The sector plays a major role in the national economy and it is the source of income and employment for the rural population (Joseph Hain, et.al. 2015). The recent livestock population of Ethiopia estimates that the country has about 57.83 million heads of cattle, 28.04 million sheep, 28.61 million goats and 60.51 million poultry (CSA, 2016). Particularly highland mixed crop-livestock farming system of Ethiopia support $2 / 3$ of the livestock population and hold about $95 \%$ of the cropped area.

These livestock subsector is also major contribution in to the overall economy. The livestock sector contributes $19 \%$ of GDP and $16-19 \%$ of the foreign exchange earnings of the country. It contributes some $35 \%$ of Agricultural GDP (or $45 \%$ if indirect contributions are taken in to account). With the rapidly growing population, increasing urbanization, and rising incomes, domestic demand for meat, milk and eggs is expected to increase significantly for the foreseeable future. Furthermore, the country's foreign exchange from livestock product is increase, especially for red meat to gulf and within Africa, as well as leather and other livestock product to Europe (MOA, 2012).

The livestock production system is virtually traditional and contributes to both subsistence and cash generation. They are only sell or slaughtered animals at an advanced age, or in case of urgent need (Ehui et al., 2000; Ayalew et al., 2003).

\section{Production and Utilization of Hides and Skins in Ethiopia}

There are a number of ways hides and skins are produced in Ethiopia individual households, rural slaughter slabs; municipal slaughter houses and mechanized, modern abattoirs.

Individual households residing in kebeles across Ethiopia produce most of the country's hides and skins, often slaughtering their animals in their backyard (Ethiopia Livestock Master Plan, 2007).

A considerable number of the raw material is derived also from slaughter slabs constructed either by local communities, regional governments or hide and skin development projects municipal slaughterhouses, local and export abattoirs and meat and meat products processing plants are other sources of hide and skin (Ahmed, 2000).

The availability of hides and skins depends on the number of cattle slaughtered. Both in beef and dairy businesses, hides and skins are recovered and taken to firms for further processing (Ahmed, 2000). Despite the prevalence of periodic drought, many killer livestock diseases and feed shortages that have adverse effects on the population of livestock, the annual livestock population and hide and skin data reveal a constant increment (MEDaC, 1999).

In Ethiopia, supply of raw hides \& skins is entirely from domestic source and are largely processed at various stages for export purpose and very little finished leather for domestic consumption. However, the local tanning industries have rather suffered from both poor quality and limited supply of the raw material, especially skins.

American Research Journal of Agriculture

Page 4 
Review on Hide and Skin Value Chain in Ethiopia

The net supply of raw hides \& skins appear to be far below the aggregate demand of the existing tanneries (CSA, 2000).

The major suppliers of sheep skins are Amhara, Oromia and the Southern Nations Nationalities and Peoples Regions (SNNPR) accounting for 34.5, 32.9 and 16.6\%, respectively, of the total sheepskins supplied to tanneries. On the other hand 45.4, 26.4, 11.7 and 11.6\% of the total goatskins supplied to tanneries are collected from Amhara, Oromia, Tigray and SNNPR, respectively. The other region's contribution is in the range of 0.02 to $2 \%$ (MOA, 1997).

The estimated off-take rate for sheep in Ethiopia is 40\%; and estimated the off-take rate for goats and cattle, which is $37 \%$ and $6.5 \%$, respectively, (CSA, 2000).

Table1. Livestock population, H\&S production in Ethiopia.

\begin{tabular}{|l|l|l|l|l|l|l|l|}
\hline \multirow{2}{*}{ No } & \multirow{2}{*}{ Area } & \multicolumn{3}{|c|}{ Livestock Population ('000heads) } & \multicolumn{3}{c|}{ Hides \& Skin production ('000 Pieces) } \\
\cline { 3 - 8 } & & Cattle & Sheep & Goat & Hide & Sheep Skin & Goat Skin \\
\hline 1 & Tigray & 2,688 & 687 & 1,760 & 188 & 227 & 617 \\
\hline 2 & Afar & 1,991 & 2,300 & 3,960 & 139 & 759 & 1,386 \\
\hline 3 & Amhara & 10,533 & 5,320 & 3,816 & 737 & 1,750 & 1,336 \\
\hline 4 & Oromia & 18,036 & 4,700 & 4,170 & 1,262 & 1,551 & 1,460 \\
\hline 5 & Somali & 1180 & 6865 & 6100 & 83 & 2265 & 2135 \\
\hline 6 & Benishangul & 310 & 59 & 200 & 21 & 19 & 70 \\
\hline 7 & S.N.N.P & 8830 & 3170 & 2651 & 618 & 1046 & 628 \\
\hline 8 & Gambella & 126 & 44 & 49 & 9 & 15 & 17 \\
\hline 9 & Harare & 34 & 6 & 19 & 2 & 2 & 7 \\
\hline 10 & Diredawa & 54 & 34 & 91 & 4 & 11 & 32 \\
\hline Total & Ethiopia & 43249 & 23185 & 22816 & 3062.8 & 7645 & 7687.5 \\
\hline
\end{tabular}

Source: Tsige , (2009); GRM International BV, Nov.,2007; Livestock Development, Master Plan Study, V. K - Hides \& Skins, and Ministry of Agriculture and Rural Development

\section{Constraints of Hides and Skins Production in Ethiopia}

$\checkmark \quad$ The environment (where the animals live) and husbandry practices (farming, transportation etc) contribute to pre-slaughter defects and consequent reduction in the quality of raw materials (Zenaw, 2012 and Mekonnen, 2012).

$\checkmark$ Any fatal disease that leads to the condemnation and destruction of the animal, or a serious disease that affects the productivity of the herd will have an adverse effect on the supply of hides and skins (Leach, 1995).

$\checkmark \quad$ Post-mortem defects comprise of inadequate bleeding, gouge marks, flay cut, putrefaction, hair slip and beetle damages, etc. (Kidanu, 2001) which are directly related to transportation, preservation and storage of the materials and hence are the product of poor management and treatment (Bultri, 2012 and Zemene and Addis, 2012

$\checkmark \quad$ Animal health problems (parasitic \& skin diseases), RISP II(,2013)

$\checkmark$ As many as one-quarter to one third of all skins processed at tanneries have various defects and are unsuitable for export purposes (Kassa, 1998)

$\checkmark \quad$ Flay cuts and gouges are a common feature on hides and skins (Koloka, 2010).

$\checkmark$ Poor handling during loading and unloading may damage quality of hides and skins (Kassa, 2005). 
$\checkmark$ Quality is the most important factors in the improvement of skin production as a whole system of collection, which is far from efficient or complete (UNIDO, 2004)

$\checkmark$ Berhe (2009) in Tigray also reported that disease and fly cut were the main defects of the hide.

$\checkmark$ Bezabih,(2014) has shown that filthiness, gauge marks and flay cut or poor pattern are the most important defects of sheep and goat skin and cattle hide in East Gojam Zone of the Amhara Regional State.

\section{Hides and Skins Marketing in Ethiopia}

During holidays and festive meals, citizens consume more meat and therefore create and supply more fresh hides. During these holiday and festival periods, tanneries will often purchase hides and skins directly from established producers or temporary purchasing posts.

Hide and skin production is significantly increased in number in Ethiopia, but the efficiency of the market is not assessed (FAO, 1999).

Tanneries process the hides or skins purchased; either in the form of air dried or salted states from their suppliers, to semi-finished or finished leather for both domestic and export markets (Arkebe, 2009).

Juhar T, Teshager D, Getachew T. (2015) revealed that Most of butchers sell their hides and/or skins to collection centers which is similar with Jabbar (2002), the butchers or meat exporters sell the hides and skins to merchants who will then export them or sell them to domestic tanneries.

In addition to that, collection centers have workers who collect sheep and goat skins from the butchers every day by going up to the butcher's house. This may have created good opportunity to butchers to sell their products directly to collection centers. This agrees with UNIDO (2004) who gave the analysis that the hides and skins produced in butcheries and abattoirs are auctioned to big traders and to tanneries, both public and private.

Also Juhar T, Teshager D, Getachew T. (2015) finding stated that the farmers hide and skin are rejected and/ or they sold the products with lower price at one time or other. This agrees with kaguyna et al (2011) who reported that, among the producers who were interviewed $85 \%$ of households and $70 \%$ of butchers said that their hides and skins have been rejected at one time or the other.

According to the findings of AGP-LMD ,2013) the marketing chain, and the resulting pricing system, is a reflection of the poor marketing system and the lack of appropriate and effective institutional framework to regulate the system.

There are different market channels in the trade of raw hides and skins prior to their reaching a tannery. The most common channels are:

Channel A: Producers---Local tanners

Channel B: Producers----Collectors--------local tanners

Channel C: Producers---Collectors---Small Traders-----big Traders ----Modern tanneries

Channel C: Producers----Small Traders----- Big Traders--------Modern tanneries

Channel D: Producers----Big Traders--------Modern tanneries

Channel E: Producers----Modern tanneries

Source: AGP-LMD, 2013; Mohammed, 2011; Sultan, 2016

AS AGP-LMD, (2013) is reviewed Channel C is the most common trading channel in the modern Ethiopian tanneries while the traditional tanneries usually trade through Channel A. 


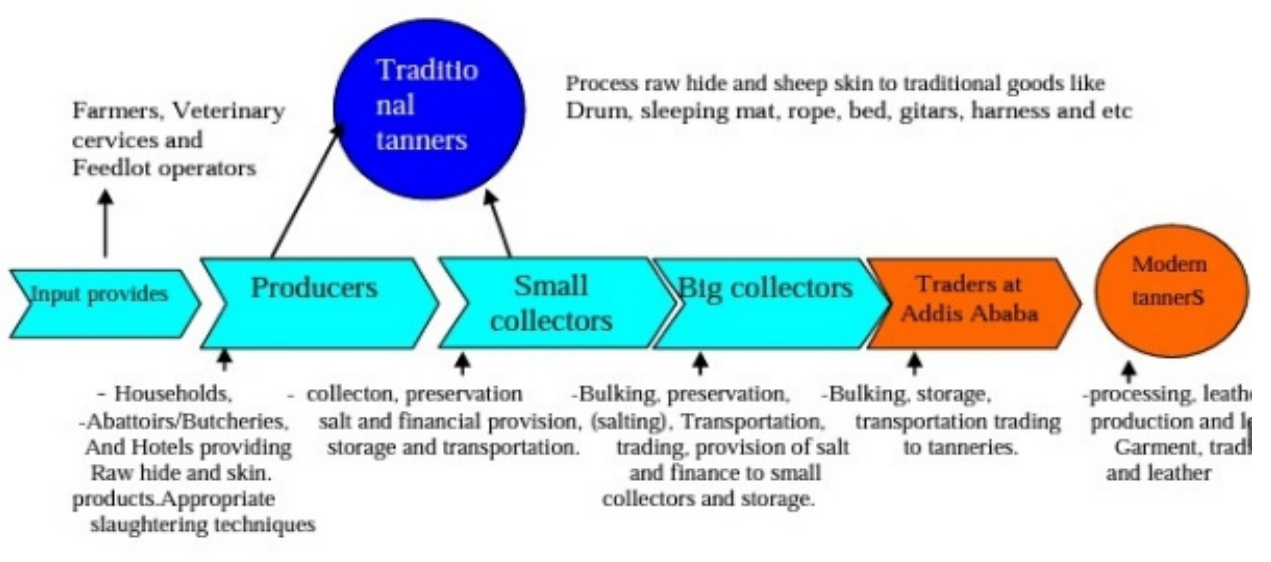

Fig1. Marketing relationship in hide and skin value chain

Source: AGP-LMD, (2013)

Alemnesh, (2015) has reviewed that most household producers sell skin or hide in the form of fresh to middlemen (brokers). Even though brokers have not license they are easily accessible to household producers and collect directly going door to door in case of urban area and by setting temporary collection point at most accessible spot in case of rural areas. This finding is line with Hadush et al., (2013) reported that $21 \%$ of respondents sell hide and skin to middlemen.

However, selling to middlemen than collection centers makes them lose better price offer since collection centers buy the products at the same price from both middlemen and household producers. In the study area marketing flow of hide and skin starts from producers (farmers, butchers) and agents could be middlemen and collection centers with final destination to tanners this is in agreement with Ahmed (2000) who reported that the market chain for raw hide and skin consists of the primary producers/consumers, who were the initial sources (individual meat consumers, rural slaughter slabs, municipal slaughter houses, abattoirs, meat processing plants), agents of traders, collectors, local tanners, regional medium/ small traders, regional/Addis Ababa big traders and tanneries.

Juhar T, Teshager D, Getachew T. (2015) argue that Farmers sell mostly fresh skins and dried hides to middlemen (82\%), who in turn sell to collection centers. On the other hand, producers who kill animals at home or backyards and are near to collection centers sell the fresh or dried hides or skins directly to collection centers(18\%). Butchers, who kill their cattle at the municipal abattoir, sell the hides to collection centers after preserving the hide in the abattoir by salting. Among 40 butchers interviewed 7(17.5\%) sell the products to middlemen, who in turn sell to collection centers, 33(82.5\%) (Table 2) sell directly to collection centers. Collection centers have workers who collect sheep and goat skins from the butchers every day by going up to the butcher's house.

According to Almnesh, (2015) the majority of hide and skin producers sell their raw materials to the market to generate income. This disagrees with the finding of Hadush et al., (2013) in Tigray region and Asegede et al., (2015) who reported that only $31 \%$ and $44.14 \%$ respectively of household respondents sell skin to formal market.

Almnesh, (2015) finding goes in line with the conclusion that large amount of money is lost due to direct rejection or costs incurred for defective skin processing (Sertse and Wossene, 2007).

Almnesh, (2015) finding is similar with ILCA (1990) and who stated that absence of market information system minimizes the share of the total value that producers receive. 
Tschirley et al., (1995) stated that the existence of information barriers results in unexploited market opportunities, seasonal gluts and produces with inadequate quality specification and control, inequitable returns to producers and fundamentally poor returns to production and marketing system as a whole

Juhar T, Teshager D, Getachew T. (2015) finding conclude that Marketing of hides and skins should depend strongly on quality, which in turn relies upon the treatment of the animal during its lifetime and the way in which the hide or skin is removed, treated, stored and transported prior to tanning. Hence, continuous awareness creation is needed on animal management and handling of hides and skins.

\section{Hides and Skins Value Chain}

To increase the level of value added retained in Ethiopia from the processing of hide and skin raw materials, the government is now requiring that all new investments in the tanning industry be capable of processing hides and skins up to the stage of finished leather (Ethiopian Investment Agency 2008).

The animal mostly (sheep, goats and cattle) at the abattoirs and slaughter slabs were handled by butchers who play the role of primary source of raw materials in the upstream, as hides and skins are considered a by-product of meat industry.

Value addition started at the abattoir, slaughter houses or slabs where skins/hides passes through many hands (traders) before reaching the tanneries. This coincides with the findings of Ismail, (2005). At the tanneries flows continues after selection/grading by hides and skins inspectors through various stages of processing until hides/skins are converted to wet blue, crust, or finished leather

The Ministry of Industry has also banned the export of crusted leather starting from December 2011 due to price hikes and scarcity of supplies (Fortune, 19 September 2011).

Increasing the quality of hides and skins requires strategies for reducing pre- and post-slaughter damage and improving preservation and handling practices.

Table2. Hides and Skins Value addition in Ethiopia

\begin{tabular}{|c|c|c|}
\hline Stages & Important Inputs & Outputs \\
\hline - Livestock Production & 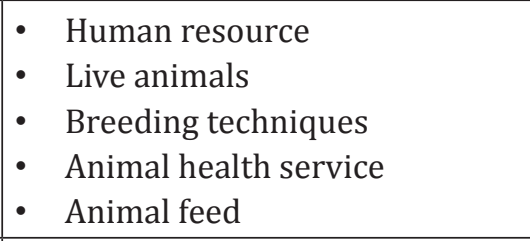 & $\begin{array}{ll}\text { - } & \text { Milk } \\
\text { - } & \text { Pulling power } \\
\text { - } & \text { animals for slaughter }\end{array}$ \\
\hline $\begin{array}{l}\text { - Slaughter Hides and } \\
\text { skins Recovery }\end{array}$ & 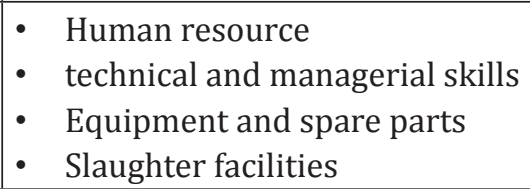 & $\begin{array}{ll}\text { - } & \text { Heavy bovine hides } \\
\text { - } & \text { Light bovine hides } \\
& \text { Goat and sheep skins }\end{array}$ \\
\hline - Tannery & $\begin{array}{ll}\text { - } & \text { Raw hides and skins } \\
\text { - } & \text { Human resource } \\
\text { - } & \text { Chemical and managerial skills } \\
\text { - } & \text { Machinery }\end{array}$ & $\begin{array}{l}\text { - } \text { heavy and light bovine leather } \\
\text { - light (sheep and goats) leather } \\
\text { - } \text { (pickled, wet blue, crust, finished) leather } \\
\text { (draditionally, value added hide and skin } \\
\text { and etc. }\end{array}$ \\
\hline
\end{tabular}

Source: Extracted from COMESA Regional Strategy for the Leather and Leather Products Value Chain. 
Review on Hide and Skin Value Chain in Ethiopia

Table3. Average Growth Rate of Bovine Hides, Sheep Skins and Goat Skins (2003-2012) in Ethiopia.

\begin{tabular}{|l|l|l|l|}
\hline \multirow{2}{*}{ Hide and skin source } & Each Year growth & Average Growth rate \\
\cline { 2 - 4 } & $\mathbf{2 0 0 3}$ & $\mathbf{2 0 1 2}$ & \% \\
\hline Bovine hides & 3.1 & 3.8 & 22.59 \\
\hline Goat /kid skins & 5.2 & 7.8 & 50.0 \\
\hline Sheep/Lamb skins & 5.3 & 8.3 & 56.60 \\
\hline
\end{tabular}

Source: FAO, World Statistical Compendium, (2012)

\section{Hide and Skin Value Chain Actors in Ethiopia}

Nebiyu, Likasa, Dr. D. Asha, (2017) has reviewed the major actors in Hide and Skin value chain are producers, farmer traders/village collectors, urban assemblers, wholesalers, retailers, hotels and restaurants, processors, and consumers. Based on the functions potential value chain actors were identified, their roles, function, value adding process, marketing and relationships were sorted out.

Table4. Hide and skin value chain Actors in Ethiopia

\begin{tabular}{|c|c|c|}
\hline Micro-Actors & Meso Actors & Macro-Actors \\
\hline - Producers & $\checkmark$ Farmer Training Centers & $\checkmark$ Financial Services \\
\hline$\checkmark$ Farmers/house holders & $\checkmark$ Cooperatives & $\checkmark$ Ethiopian Leather Industries \\
\hline$\checkmark$ Rural Slaughter Slabs Operators & organizations & Association (ELIA) \\
\hline$\checkmark$ Municipal Slaughter Houses & $\checkmark$ Non-Governmental Organizations & $\checkmark$ Leather Industry Development \\
\hline$\checkmark$ Operators (Bigger and Medium & $\checkmark$ National Agricultural Research & Institute (LIDI) \\
\hline Abattoirs) & System & $\checkmark$ Government Stakeholders and \\
\hline$\checkmark$ Mechanizedabattoirs & $\checkmark$ Agricultural & Regulations \\
\hline Abattoirs) & VocationalEducation and Training/ & $\checkmark$ Federal, Regional and Woreda \\
\hline - Raw Hides and Skins Recovers & Higher & level AGP Coordination offices \\
\hline and Collectors & $\checkmark$ Agriculture Development Partners & \\
\hline$\checkmark$ Intermediary Traders / Collectors & Linkage Advisory & \\
\hline$\checkmark$ LargeTraders/WholesaleSuppliers & & \\
\hline to Tanneries & & \\
\hline - Tanneries/Leather processors & & \\
\hline
\end{tabular}

Source: Nebiyu, Likasa, Dr. D. Asha, (2017) and (RISP II, 2013)

\section{Constraints and Opportunities of Hides and Skins Value Chain in Ethiopia}

The main constraints adversely affecting the production and marketing of hides and skins are defect, the utilization of HS for traditional household items, the existence of cross border illicit trade and misuse of the raw material due to lack of awareness, result in a low recovery rate and ultimately shortages of raw HS in the central market (MEDaC, 1999).

Similarly, the other constraints of hides and skins marketing faced were reflections of the economic policy which were characterized by socialist-oriented development and centralized planning system: nationalization of major industries, financial institutions, allocation of quotas, fixing prices, legal monopoly of corporations, restriction of trade movement and the like (Girma, 2002).

Apart from the problems that stemmed from the system, the main constraints in the marketing of hides and skins included an inadequate network of primary buyers, lack off abilities for slaughtering, preservation, storage and transportation, 'lack of incentives for improvement' and limited effectiveness of government extension service and other manmade and natural damage inflicted on the raw hides and skins downgrades quality (Ahmed, 2000). 
Review on Hide and Skin Value Chain in Ethiopia

Nebiyu , Likasa, and Dr. D. Asha in their research Value chain inefficiencies in all three livestock categories resulted in lost income, employment and market opportunities for

$>$ cattle hides because of insufficient collection;

$>$ sheepskin due to insufficient collection and production; and

$>$ Goatskin from both insufficient collection and production.

AGP-LMD, (2013) and (ILRI, 2013) research has reviewed that there are many challenge and opportunities for hide and skin value chain in Ethiopia.

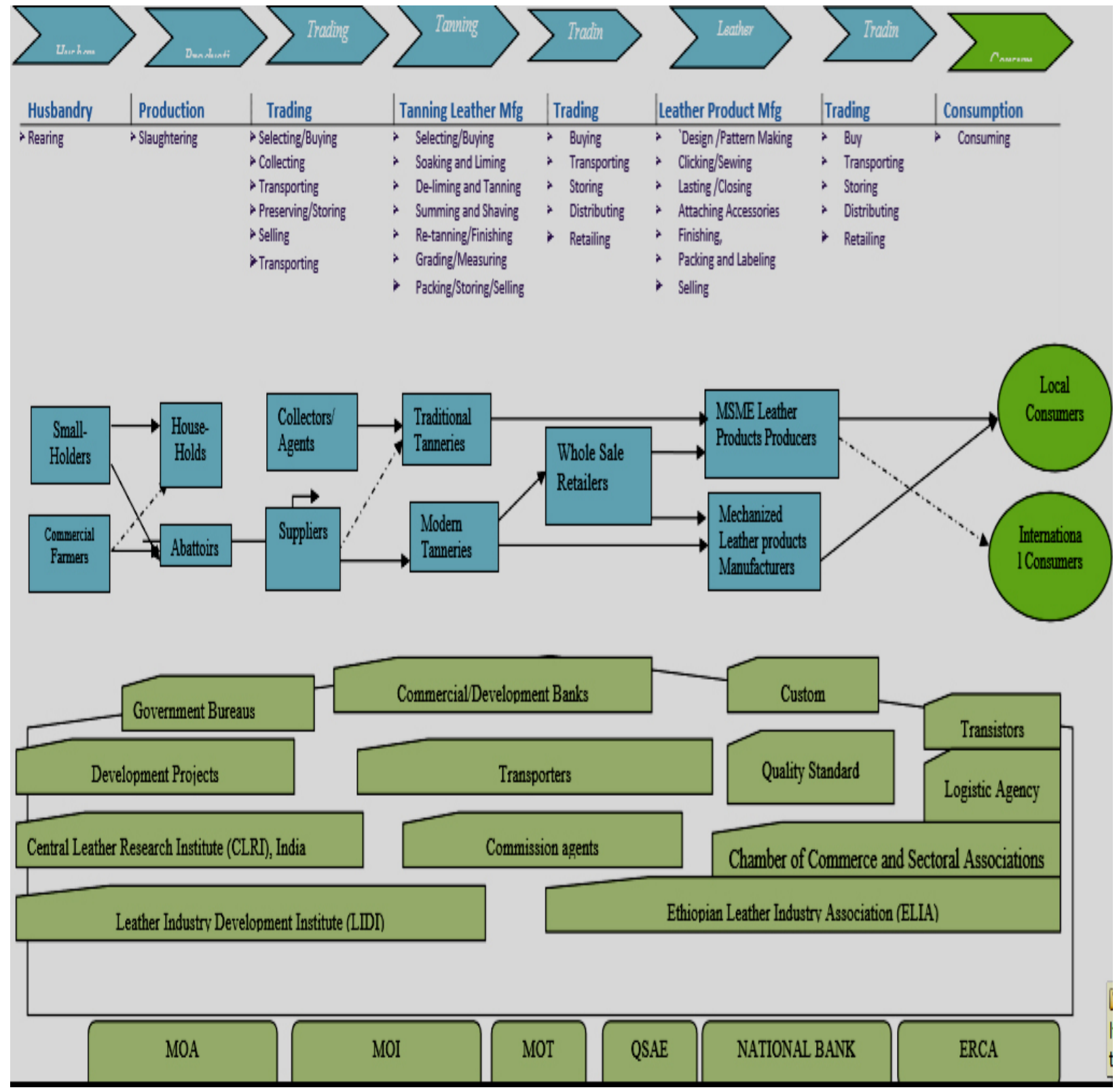

Fig2. Value chain map of HSL

Source: (AGP-LMD, 2013) 
Review on Hide and Skin Value Chain in Ethiopia

Table5. Constraint and opportunities of hide and skin in Ethiopia

\begin{tabular}{|c|c|}
\hline Constraints & Opportunities \\
\hline$\checkmark \quad$ Limited supply of skins & \\
\hline$\checkmark \quad$ Poor quality of hides and skins & $\checkmark$ Competitive advantages are known for the \\
\hline$\checkmark \quad$ Poor animal husbandry & Ethiopian sheepskins. \\
\hline$\checkmark \quad$ Post-mortem practices & $\checkmark \quad$ The government has given due consideration \\
\hline$\checkmark \quad$ Improper preserved hides and skins & to overcome this animal health problems and \\
\hline$\checkmark \quad$ Lack of price incentives & starting to implement demonstrations. \\
\hline$\checkmark \quad$ Capital and finance throughout the value chain, & $\checkmark$ Value Chain Analysis of Ethiopian Industrial \\
\hline$\checkmark \quad$ Quality grading, and prices not based on quality & Leather Sector for Investment Opportunity \\
\hline$\checkmark \quad$ Lack of strong technology transfer efforts & $\checkmark \quad$ The creation of a trade mark or product image \\
\hline$\checkmark \quad$ Reflections of the economic policy & "Made in Ethiopia. \\
\hline $\begin{array}{l}\checkmark \text { Poor access of the producers and local traders in } \\
\text { market information, not only the price but also } \\
\text { requirements from the tanneries and end market. }\end{array}$ & $\begin{array}{l}\checkmark \text { Existence of regional and sub-regional market } \\
\text { for leather products (COMESA). }\end{array}$ \\
\hline
\end{tabular}

\section{CONCLUSION AND RECOMMENDATION}

\section{Conclusion}

The review was undertaken with the objective of value chain of hide and skin in Ethiopia.

Hides and skin is an important strategic sector for the economic and industrial development of Ethiopia .For hides and skins there is failure in translating market information (grades, standards) into price incentives to manage quality and furnish more supply through price information.

Therefore to ensure rapid and sustainable growth of the hide and skin and its by products in Ethiopia requires changing the traditional practices and mind set implanted in the life style of all players in the value addition process starting from the way animals are raised and handled up to which consumer goods are sold locally and internationally. In order to provide hides and skin of high and acceptable quality, there is the need to improve animal husbandry techniques, animal slaughtering facilities, tanneries and leather goods manufacturing industries, enforce rules that are designed to improve leather sector, increase number of veterinarians, flyers and livestock extension officer. The challenges along the chain are many and revolve around two key issues: 1) supply issues - insufficient supply to meet even the most minimal market demand, and 2) poor quality (e.g. scarred, diseased, improperly flayed) hides and skins, which directly limit the market potential of the downstream products such as shoes, gloves and apparel. These challenges are implicated with the low tannery capacity utilization, lack of price incentive for producers along the chain, and limited specialization and competition.

\section{Recommendation}

$\checkmark$ Creation of awareness among extension staff, butchers, collectors, tanners and other stakeholders and the general public of the economic importance of hides and skins are very important.

$\checkmark$ Clear policy and strategy for the development of leather sector should be developed by member State that have not done so far.

$\checkmark \quad$ Developing Clear pricing system based on grading and standard of hide and skin and improving access to market information 
$\checkmark$ Various stakeholders should be involved in the value chain to support in the area of funding/institutional credit facilities especially to hides and skins traders.

$\checkmark$ Provide training to a wide range of people in both urban and rural areas in slaughtering and flaying skills, in preservation techniques, and in applying to identify the grading and standards skill of hides and skins for the slaughters.

$\checkmark$ Offering price-based incentives based on size and grades of hides and skins

$\checkmark \quad$ The leather factories /tanneries should establish strategic alliance with suppliers of raw H\&S and motivate them appropriately for their supply of quality H\&S.

$\checkmark$ Encouraging collaboration between tanneries and abattoirs/slaughterhouses

$\checkmark$ Encouraging more private sector investment in the animal health sector to extend the reach and benefit of animal health research, drugs, clinics and services.

\section{REFERENCES}

1. Addis Ababa Agricultural Bureau, (1998): Hide and skin is balance collected from the remaining regions of the country.

2. Abebayhu T. and Kibrom M. (2010): Study on Ectoparasitic defect of processed skin at Sheba tannery, Tigray, Northern Ethiopia. Tropical Animal Heath Production, DOI 10.1007/s11250-010-9625-z.

3. Adugna A. (2004): Guideline document for hides and skins quality and marketing improvement survey of Sheba Tannery in Tigray, unpublished. Addis Ababa.

4. AGP-Livestock Market Development Project, (2013)

5. Ahmed M. (2000): Development potential and constraints of hides and skins market in Ethiopia.

6. Arunga R. (1995): The role of hides, skins, leather and leather products for sustainable economic growth. Proceeding on Regional Workshop 28-30July 2010, Addis Ababa, Ethiopia.

7. Asegede M., Bisrat A., Hagos Y. and Gugsa G. (2015) livestock market value chain assessment in selected sites of Tigray, North Ethiopia: challenges and opportunities for enhancing animal product export. Global veterinarian, 14(1) 4852

8. Asfaw A. (2002): Challenges and Prospects of the Leather Industry in Relation to Export promotion. In: Parenti, A. (ed.) Proceedings of Challenges and Solutions for Ethiopian Leather Industry, 10December 2002, UNIDO and Addis Ababa.

9. Ayele S., Assegid W., Jabbar M.A., Ahmed M. and Belachew H. (2003): Livestock marketing in Ethiopia: A review of structure, performance and development initiatives.

10. Behailu Amade MSC thesis (2015): Assessment of Pre- and Post Slaughter Hide and Skin Defects and Their Association with Carcass Condemnation in Addis Ababa University.

11. Berhe A. (2009): Assessment of hides and skins market in Tigray Region: The case of Atsbi Wemberta woreda, Eastern Tigray, Institutes of Regional and Local Development Studies, Addis Abeba University, Addis Ababa, Ethiopia

12. Bezabih A. (2014): The Leather Sector Growth strategies through Integrated Value Chain. Ethiopian Development Research Institute (EDRI), Addis Ababa, Ethiopia. 


\section{Review on Hide and Skin Value Chain in Ethiopia}

13. CSA (2007): Ethiopia Agricultural sample enumeration, statistical report on livestock population Central Statistical Authority (CSA), Addis Ababa, Ethiopia.

14. CSA (2009): Review to improve estimation of livestock contribution to the national GDP. Central Statics Agency, Addis Ababa Ethiopia.

15. CSA (Central Statistical Authority), (2016): Report on Livestock and livestock characteristics in Dendi district.

16. CSA (2009): Review to improve estimation of livestock contribution to the national GDP. Central Statics Agency, Addis Ababa Ethiopia CSA (2011): Ethiopian Agricultural Sample Enumeration, 2011/2012, Central Statistic Authority, Federal Democratic Republic of Ethiopia.

17. Darge A. (1995): The Feature of the Ethiopian Hides, Skins, Leather and Leather Products Development. General Report. Addis Ababa.

18. Dawit. (2010) and Marshal, (2011): concept of profit margin that deducts operating expense from marketing margin.

19. EIA (Ethiopian Investment Agency). 2008. Investment opportunity profile for tanning of hides and skins up to finished level in Ethiopia, Addis Ababa, Ethiopia: EIA. Fortune. September 19, 2011. Addis Ababa, Ethiopia. Gonzalez, V.M. 1981. Hides and skins improvement manual.

20. International Journal of Advanced Research in ISSN: 2278-6236 Management and Social Sciences Impact Factor: 6.943 Vol. 6 | No. 2 | February 2017 www.garph.co.uk IJARMSS | 132

21. ELMP (Ethiopia Livestock Master Plan), (2007): hide and skin are produced in Ethiopia individual house holds, rural slaughter slabs, municipal slaughter houses and mechanized, modern abattoirs.

22. EIA (Ethiopian Investment Agency). 2008. Investment opportunity profile for tanning of hides and skins up to finished level in Ethiopia, Addis Ababa, Ethiopia: EIA. Fortune. September 19, 2011. Addis Ababa, Ethiopia. Gonzalez, V.M. 1981. Hides and skins improvement manual.

23. ELMP (Ethiopia Livestock Master Plan), (2007): hide and skin are produced in Ethiopia individual households, rural slaughter slabs, municipal slaughter houses and mechanized, modern abattoirs.

24. FAO (1995): Hides and skins for the tannery industry, FAO agricultural service bulletin,123, By, Lan, Leach, consultant, Rome, Italy, 1995.

25. FAO (2011): Livestock and livestock characteristics. Rep 2. Addis Ababa: Federal democratic republic of Ethiopia, 2011.

26. Girma A. (2002): The performance of hides and skins marketing in the Amhara national regional state; MSc. Thesis. Alemaya university, Alemaya, Ethiopia.

27. Girma M. (2003): Opportunities and Challenges of Hides and skins Trade opportunities and Challenges of Livestock Marketing in Ethiopia.

28. GRM International BV. Undated. Federal Democratic Republic of Ethiopia. Ministry of Agriculture and Rural Development. Livestock Development Master Plan Study, Phase II Volume 
29. GRM International BV, Nov. 2007, Livestock Development Master Plan Study, V. K - Hides \& Skins, Ministry of Agriculture and Rural Development

30. Hadush B., Abdulkadir K., Alula G. and Mengstu A. (2013): investigation of farmers on the value chain of leather industry in northern Ethiopia; challenges, constraints and opportunities for linking small holder farmers to markets. International Journal of social relevance and concern. 1: 17-20.

31. ILCA (1990): Annual report and program high light ILCA, Addis ababa and Ethiopia. International livestock center for Africa (ILCA).

32. ILO. Government of Ethiopia and the World Bank Group. 2006. An overview of the integrated value chain analysis of selected strategic sectors, Global Development Solutions. GRM International BV. Undated. Federal Democratic Republic of Ethiopia.

33. ISO (2000): International Organization for Standardization Test Methods of Tear strength and Tear load, Leather and Leather products Technology Institute, Addis Ababa, Ethiopia, International Organization for Standardization (ISO 33762).

34. Jabbar M.A. and Benin S. (2002): Trader behavior and transaction costs. In: Live animal marketing in Ethiopia. Paper presented at the workshop on improved land management and agricultural market development in the Ethiopian highlands. Addis Ababa, Ethiopia, 19-20 February 2004. Pp. 23.

35. Kebede, N. and Fetene, T. 2012. Population dynamics of cattle ectoparasites in Western Amhara National Regional State, Ethiopia. Journal of Veterinary Medicine and Animal Health 4(1):22-26. LLPI (Leather and Leather Products Institute). 2002.

36. Koloka O. and Morek J. C. (2010): Performance of hides and skins subsector in Botswana: A critical review Livestock Research for Rural Development, 22:150175.

37. Kotler P. and Armstrong G. (2003): Principles of Marketing, 10th Edition, Hall of India Private limited, New Delhi, Pp. 5-12.

38. Leather and Leather Products Institute - Prospectus. Addis Ababa, Ethiopia: LLPI. MoFED. 2010. Growth and Transformation Plan (GTP) of Ethiopia. Addis Ababa, Ethiopia: MoFED.

39. Ministry of Agriculture International Livestock Research Institute,2013) Hides, skins and leather value chain vision and strategy for Ethiopia.

40. MOA: Livestock development master plan study. Phase II Volume 1a. Executive summary of main report and sub master plans, Addis Ababa, Ethiopia.

41. MoARD (2009): The effect of skin and hide quality on domestic and export market and evaluation of the campaign against ectoparasitic of sheep and goat in Amhara, Tigray, and Afar region, official report to Region and other sector s, Addis Ababa, Ethiopia, Ministry of agriculture and rural development (MoARD).

42. Mohammad A., Jabbar S., Berhanu G. and Simeon E. (2002): Essential Actions to Meet Quality Requirements of Hides, Skins and Semi-Processed Leather from Africa. A Report Prepared for the Common Fund for Commodities Amsterdam, Netherlands.

43. Nebiyu Likasa, Tadele Melaku Challa, Dr. D. Asha Latha (2017), value chain analysis of hide and skin in dendi district, west shoa, MSc. Thesis. Ambo university, Ambo, Ethiopia. 
Review on Hide and Skin Value Chain in Ethiopia

44. Porter. E. Micheal, 1985. Competitive Advantage-Creating and Sustaining Superior Performance, New York.

45. Tsige Birhane (Sept. 2009) Value Chain Analysis of Ethiopian Leather Industrial Sector MSc. Thesis .Addis Abeba university, Addis Abeba, Ethiopia

46. USAID (Unite state agency and international development), (2013): Agriculture Growth project Livestock Market Development for Investment Opportunity

47. Zewdu K. (1995): Hide and skins in Ethiopia. pp. 6-14. Preceding the 2nd Annual Conference of Ethiopian Society Animal Production (ESAP) 26-27 May1982, Addis Ababa, Ethiopia.

Citation: Tilahun Kenea. "Review on Hide and Skin Value Chain in Ethiopia". American Research Journal of Agriculture, vol 5, no. 1, 2019, pp. 1-15.

Copyright (C) 2019 Tilahun Kenea. This is an open access article distributed under the Creative Commons Attribution License, which permits unrestricted use, distribution, and reproduction in any medium, provided the original work is properly cited. 